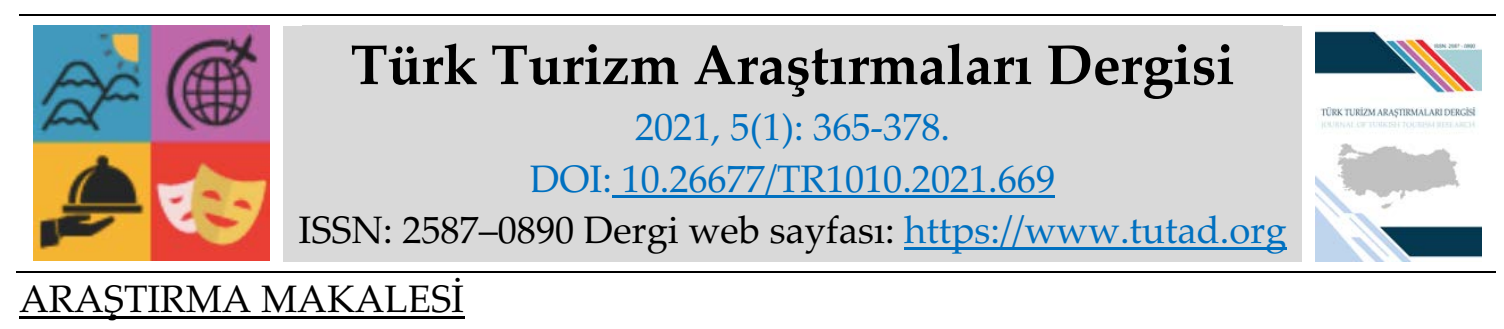

\title{
Otel İşletmelerinde Yerel Mutfak Kültürü: Mardin Örneği
}

Öğr. Gör. Dr. Şeyhmus DEMİRCAN, Muğla Sıtkı Koçman Üniversitesi, Muğla Meslek Yüksekokulu, Muğla, e-posta: seyhmusdemircan@mu.edu.tr

ORCID: https://orcid.org/0000-0002-2475-0207

Öğr. Gör. Dr. Taner DALGIN, Muğla Sıtkı Koçman Üniversitesi, Muğla Meslek Yüksekokulu, Muğla, e-posta: tanerdalgin@mu.edu.tr

ORCID: https://orcid.org/0000-0002-7645-1989

Öğr. Gör. Gözde Nur COŞKUN, Mardin Artuklu Üniversitesi, Mardin Meslek Yüksekokulu, Muğla, e-posta: gozdenurcoskun@artuklu.edu.tr

ORCID: https://orcid.org/0000-0002-5703-9198

Öz

Yöresel yiyecek ve içeceklerle ilgili beklenti ve deneyim, destinasyonun marka algısını etkileyen önemli bir unsurdur. Destinasyon hakkındaki pozitif etkiler tekrar ziyaret niyetinde de etkili olmakta ve destinasyonun mutfak kültürü hakkındaki imajına katkı sağlamaktadır. Bu araştırmanın amacı otellerin menülerinde yer alan yöresel yemeklerin yöreyi ne kadar yansıttığını araştırmaktır. Bu amaçla yöresel yiyecek ve içeceklerin o destinasyondaki konaklama işletmelerinin menülerinde yer alma durumunu ve müşteriler tarafından talep edilme durumu belirlenmiştir. Gerek kültürü gerek tarihi ile birçok medeniyete ev sahipliği yapmış olan Mardin, zengin mutfak kültürü nedeni ile çalışma alanı olarak seçilmiştir. Mardin ilindeki 3, 4 ve 5 yıldızlı otellerin üst ve orta kademe yöneticileri ve mutfak personeli ile yarı yapılandırılmış mülakat (görüşme) formu üzerinden mülakat yapılmıştır. Araştırmalar sonucunda otellerin menülerinde yöresel yiyecek ve içeceklerin bir kısmına yer verdikleri görülmektedir. Ancak, bazı yöresel yemekler yapımının zahmetli olması ve uzun sürmesi sebebiyle, sadece banket organizasyonu gibi önceden tüketimin belirli olduğu özel etkinlikler için hazırlanmaktadır. İşletmelerin menülerinde yöresel yemeklere yer verseler de bu yemeklerin tanıtımı ve markalaştırılması ile ilgili yeterince çaba göstermediği belirlenmiştir.

Anahtar Kelimeler: Gastronomi Turizmi, Türk Mutfağı, Yöresel Mutfak, Mardin.

Makale Gönderme Tarihi: 18.11 .2020

Makale Kabul Tarihi: 07.03.2021

Önerilen Atıf:

Demircan, Ş., Dalgın, T. ve Coşkun, G. N. (2021). Otel İşletmelerinde Yerel Mutfak Kültürü: Mardin Örneği, Türk Turizm Araştırmaları Dergisi, 5(1): 365-378.

(C) 2021 Türk Turizm Araştırmaları Dergisi. 


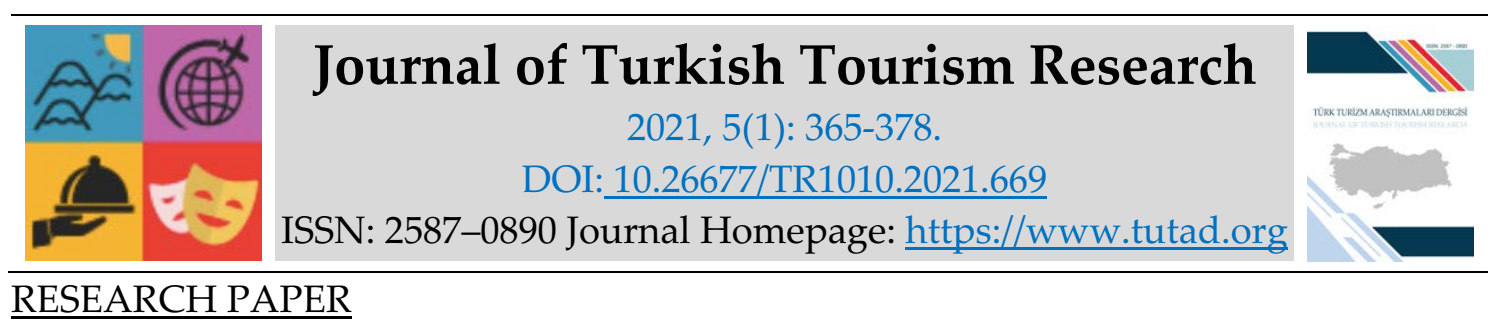

\title{
Local Culinary Culture in Hotel Management: The Example of Mardin
}

Dr. Şeyhmus DEMİRCAN, Muğla Sıtkı Koçman University, Muğla Vocational School, Muğla, email: seyhmusdemircan@mu.edu.tr

ORCID: https://orcid.org/0000-0002-2475-0207

Dr. Taner DALGIN, Muğla Sıtkı Koçman University, Muğla Vocational School, Muğla, e-mail: tanerdalgin@mu.edu.tr ORCID: https://orcid.org/0000-0002-7645-1989

Lecturer Gözde Nur COŞKUN, Mardin Artuklu University, Mardin Vocational School, Muğla, email: gozdenurcoskun@artuklu.edu.tr

ORCID: https://orcid.org/0000-0002-5703-9198

\begin{abstract}
Expectation and experience about local food and drink, is an important factor affecting destination brand perception. The positive effects about the destination also affect the intention to visit again and contribute to the image of the destination about the culinary culture. The aim of this research is to investigate how much the local dishes in the menus of the hotels reflect the region. For this purpose, it was determined that the local food and beverages were included in the menus of the accommodation establishments in that destination, and the status of being requested by the customers. Mardin, which has hosted many civilizations with its culture and history, has been chosen as the study area because it is so rich in culinary culture. The sample of the study was interviewed with the top and middle level managers and kitchen staff of 3-, 4- and 5 -star hotels in Mardin with a semi-structured interview form. As a result of the researches, it is seen that they contain some of the local foods and beverages in the menus of the hotels. However, due to the troublesome and lengthy making of some local dishes, they are prepared only for special events such as banquet organization where pre-consumption is certain. Although the businesses included in the research include local dishes in their menus, it has been determined that they do not make enough efforts to promote and brand these dishes.
\end{abstract}

Keywords: Gastro Tourism, Turkish Cuisine, Regional Cuisine, Mardin.

Received: 18.11 .2020

Accepted: 07.03.2021

Suggested Citation:

Demircan, Ş., Dalgın, T. and Coşkun, G. N. (2021). Local Culinary Culture in Hotel Management: The Example of Mardin, Journal of Turkish Tourism Research, 5(1): 365-378.

(c) 2021 Türk Turizm Araştırmaları Dergisi. 


\section{Gíriş}

Turizm, günümüz koşullarına bağlı olarak sürekli gelişen, değişen, yenilenen ve birçok sektörle entegrasyon içinde faaliyet gösteren bir sektördür. Turizm sektöründeki değişimlerin en önemli kaynağı insanların turistik ihtiyaçlarında ortaya çıkan değişimlerdir. Bu değişimin bir sonucu olarak farklı turizm türlerine olan ihtiyaç artmaktadır (Lordkipanidze vd., 2005: 788). İnsanların refah düzeylerinin ve boş zamanlarının artması, turizmin bir lüksten öte bir ihtiyaca dönüşmesi, teknolojik gelişmeler sonucunda uzak mesafelere ulaşımın kolaylaşması ve insanların kültüre olan ilgilerinin artması, turizm olgusunun gelişiminde önemli rol oynamıştır. İnsanların dinlenmek ve boş vakitlerinde kaliteli zaman geçirmek için tercih edecekleri destinasyon seçiminde birçok çekicilik unsuru etkili olmaktadır. Bu çekicilik unsurlarından birisi de o destinasyonun gastronomi turizmi kapsamında değerlendirilebilecek yerel yiyecek ve içecek çeşitliliğidir. Destinasyonlardaki yeme-içme ihtiyacına yönelik sunulan hizmetlerin içeriği ve çeşitliliği, çoğu zaman turistik ürünün içeriğini zenginleştiren bir unsur olmakla birlikte, gastronomi turizmi, kültür turizmi gibi alternatif turizm türlerinde turistik ürünün temel unsuruna dönüşmektedir. Farklı kültürlerdeki gastronomi anlamındaki çeşitlilik insanların merakını cezb etmekte ve bu merak insanları farklı lezzetlerin olduğu bölgelere seyahat etmeye yöneltmektedir (Hjalager ve Richards, 2004).

Kültürel anlamda çekilik unsuru oluşturan destinasyona ait gelenekler, doğal yapılar gibi çekicilik unsurlarının yanında, o yöreye ait yöresel yemekler de önem arz etmektedir (Kızılırmak vd., 2014). Yöresel yemekler bir ülkenin, bir destinasyonun kimliğini belirleyen önemli değerlerdir. Bir destinasyona ait yemek kültürü oradaki yaşanmışlıklara ev sahipliği yapmasından dolayı (Güler vd., 2016) özgün bir nitelik taşımakta ve ziyaretçilere benzersiz bir deneyim vaat etmektedir. O yörede yapılan yemek, o yöreye ait kültür hakkında da ipuçları taşımaktadır (Bucak ve Ateş, 2014). O yöreye ait farklı yemeklerin varlığı, diğer yörelere karşılaştırıldığında o yöreye artı bir değer kazandıracaktır (Yüncü, 2010). Özellikle, turizm gelirlerini artırmak amacında olan ülkeler ve şehirleri, turizm faaliyetlerini zenginleştirmeye yönelik olarak sahip oldukları gastronomi öğelerini ön plana çıkarmaya çalışmaktadır (Mil ve Denk, 2015). Ayrıca, destinasyona ait yöresel yemeklerin, turistlere hizmet sunan otel ve restoran işletmeleri tarafından sunulması, yöresel yemeklerin zaman içerisinde yok olmasını engellemekle birlikte, gastronomi unsurunun turistik amaçlarla kullanılmasını sağlayacaktır.

$\mathrm{Bu}$ çalışmada yöresel mutfağın otel işletmeleri menülerinde kullanım düzeyinin belirlenmesi amaçlanmıştır. Otel işletmelerinin bölgeyi ziyaret eden turistlere, yörenin yeme içme kültürünü ve gastronomi turizmi anlamındaki çekiciliklerini ne derecede yansıttıkları ve bu amaçla neler yaptıkları araştırmanın odaklandığı temel konudur. Çalışmanın teorik kısmında öncelikle gastronomi ve gastronomi turizmi kavramları açıklanmaya çalışılmış, yöresel yemek kültürüne değinilmiş daha sonra Mardin mutfağı yöresel yemek örnekleri ile anlatılmaya çalışılmıştır. Bugüne kadar kültür turizmi ile ön plana çıkmış olan Mardin ilinde bulunan otel işletmelerinde yöresel yemeklerin kullanım durumu tespit etmek ve yörede gastronomi turizmine yönelik otel işletmelerine çeşitli önerilerde bulunmak araştırmanın literatüre sağlamayı hedeflediği katkılardır.

\section{Gastronomi Turizmi}

Dünyada rekabet ortamında yaşanan gelişmeler turizm endüstrisine de yansımaktadır. Turizmden pay almak isteyen ülkeler, turizmin sürekli hale gelmesi ve çeşidinin arttırılması noktasında harekete geçmektedir. Bunun bir sonucu olarak; ön plana çıkan alternatif turizm türlerinden birisi de gastronomi turizmidir. Farklı deneyim sağlamak ve bu deneyimlerinden 
tatmin olmak isteyen turist kitlesinin odaklandığ 1 konulardan birisi yeme-içme kültürüdür. Yemek ve kültür kavramını kendi içerisinde birleştiren gastronomi kavramının birçok tanımı bulunmaktadır. Gastronomi kavramı en kısa tanımlamasıyla iyi yemek yapma sanatı olarak ifade edilirken, bu alanda çalışan araştırmacılardan bazıları gastronomi kavramını kültür ve yemekler arasındaki ilişki olarak yorumlamışlardır (Johns ve Clarke, 2001; Johns ve Kivela, 2001). Gastronomi en genel anlamıyla, "iyi yemek yeme sanatı" ve "belirli bir bölgede görülen özel pişirme usul ve gelenekleri" olarak tanımlanmaktadır (De Silva, 2003 akt. Mil ve Denk, 2015: 1). Hatipoğlu (2010) gastronomiyi yiyecek ve içeceklerin tarihsel gelişme sürecinden başlayarak tüm özelliklerinin ayrıntılı bir biçimde anlaşılması, uygulanması ve geliştirilerek günümüz şartlarına uyarlanması çalışmalarını kapsayan aynı zamanda bilimsel ve sanatsal unsurlarla katkı sağlayan bir bilim dalı olarak tanımlamaktadır. Yapılan tanımlarda ve çalışmalarda gastronomi kavramı; “bulunduğu yörenin kültürel mirası olmuş yemekleri o yöreye has malzeme, pişirme ve sunum teknikleri kullanarak görsel bir şov haline getirme sanatı" olarak ifade edilmektedir.

Gastronominin ilgi alanına bakıldığında hangi yerde, hangi zamanda, ne şekilde, ne kadar, ne yenip yanında ne içileceğine dair öneri ve yol gösterme konularını kapsadığı söylenebilir (Üner, 2014: 16). Gastronomi turizmi insanların özgün niteliğe sahip yeme-içme olanaklarını deneyimleme motivasyonu çerçevesinde gerçekleşen turizm faaliyetlerini kapsamaktadır. İnsanların herhangi bir restorana gidip orada yemek yemesi gastronomi turizmi olarak ifade edilmezken, her zamankinden farklı bir ürünü tüketme dürtüsü ile seyahat etmesi, gastronomi turizmi kapsamında değerlendirilmektedir (Akgöl, 2012: 24). Yüncü (2010), gastronomi turizmini, motivasyon kaynağı özel bir yemeğin tadımını veya bir yemeğin üretim aşamalarını görmek amacıyla, yöresel veya kırsal alanları, yiyecek üreticilerini, restoranları, yemek festivallerini ve özel alanları ziyaret etmek olarak tanımlamaktadır. Gastronomi turizmi açısından yapılan aktiviteler, bu amaçla gelmiş turistlere farklı deneyim sağlanması, destinasyonun farkındalığının arttırılması ve farklı ülkelerden gelen birçok insan ile kültürel anlamda kaynaşmanın sağlanabilmesi açılarından önemli derecede katkılar sağlamaktadır (Bilgili vd., 2012). Gastronomi turizmi, destinasyondaki yöresel yemek mirasının korunmasına katkı sağlamakta, bölgedeki tarım ve hayvancılık faaliyetlerinin gelişmesini sağlayacak fırsatları ortaya çıkarmaktadır.

Gastronomi olgusu, turistlerin destinasyon seçiminde de etkili olabilmektedir (Bucak ve Aracı: 2013; Okumuş vd., 2007). Dünya turizmindeki payını artırmak isteyen ülkeler, turizmin çeşitlendirilmesi ve sürekliliğinin sağlanması için ülkelerin turistik ürün bileşenlerinden cazibeçekicilik unsurunu yeterli bulmayıp kültürel öğeleri, özellikle de gastronomi unsurlarını ön plana çıkarmak istemektedirler (Mil ve Denk, 2015: 2). Gastronomi alanında çalışmış kişilere göre dünyanın en güzel ve zengin çeşidinin bulunduğu mutfaklar Türk, Çin ve Fransız mutfaklarıdır (Yergaliyeva, 2011: 62; Mil ve Denk, 2015). Sayısız medeniyetin yeşerdiği, yerleştiği ve tarihe karıştığı Anadolu coğrafyasında gelişen Türk mutfağı, gerek etnik ve kültürel birikimi, gerekse coğrafi özellikleri dolayısıyla, binlerce yıllık bir sürecin ardından dünyanın en zengin üç mutfağı arasında gösterilen eşsiz bir yemek geleneğine sahip olmuştur (Kan ve Kaynakçı, 2009: 268).

\section{Yerel Yemek Kültürü}

Günümüzde birçok turist farklı bir deneyim kazanmak ve yeni şeyler keşfetmek amaciyla yiyecek ve içecek kültürü üzerine seyahat etme eğilimi göstermektedirler. Buda turizm çeşitlenmesi açısından önemli gelişmelerden biridir. Somut olmayan kültürel miras olarak görülen yerel mutfak kültürü insanların dikkatini çekerek yabancı oldukları mutfaklara karşı merak oluşmaktadır. Bu meraklarını gidermek ve yeni mutfaklar keşfetmek için insanlar uluslararası, hatta kıtalararası seyahatlere başlamışlardır (Semerci, 2018). Son yıllarda hızlanan küreselleşme 
sürecinin etkisi ile hem toplumlar arası kültürel etkileşim artmış, hem de insanlar kültürel konulara daha fazla ilgi duymaya başlamıştır. Kültürel çekicilikler arasında, ziyaret edilen yerin geçmişten günümüze ulaşan ve yaşatılan, gelenek ve görenekleri, folkloru, kutlamaları, doğal ve tarihsel yapıları ve yöresel mutfağı bulunmaktadır (Kızılırmak vd., 2014).

Kültürün önemli bileşenlerinden birisi olan yemek kültürü, ait olduğu topluluğun tarih içerisindeki gelişiminin bir yansımasıdır ve özgün bir nitelik taşımaktadır. Yöresel yemek kültürü, özgün niteliği sebebiyle destinasyonlara rekabet avantajı sağlayabilecek önemli bir turistik arz unsurudur. O bölgeye has yemekler o bölge için artı bir kültürel değer oluşturmaktadır. Bireyler, açlık ihtiyaçlarını gidermenin ötesinde, bir yöredeki yemekleri yerinde tadarak farklı bir deneyim kazanmak istedikleri için turizm olayına katılım göstermektedir. Bir yöreye özgü pişirme teknikleri kullanılarak pişirilen, tüketilmesi ve sunuluş şekli ile o yöreye ait özellikler gösteren ve o yörede gelenek haline gelmiş yiyecek ve içecekler yöresel yemek olarak adlandırılmaktadır (Büyükşalvarcı vd., 2016). Gıda maddelerinin farklı işlem ve yöntemlerle hazırlanması suretiyle elde edilen yöresel yemekleri, insanın özel tecrübe ve gayretleriyle ulaştığı bir sonuç, gelişme, hayat tarzı ve insan-coğrafya ilişkisi olarak nitelendirmek gerekir (Köten vd., 2010: 515). Yöresel yemekler, o bölgede gelenek haline gelmiş, kültüre yerleşmiş ve halk tarafından diğer yemeklerden üstün tutulan yiyeceklerdir (Mil ve Denk, 2015: 1). Yöresel yemeklerin oluşumunda coğrafi konum, üretim şekli, tarihsel gelişim, ekonomik ve kültürel ilişkiler, inanç ve etnik durum gibi faktörler etkili olabilmektedir (Hatipoğlu vd., 2013). Yöresel yemekler, kültürel mirasın bir öğesi olup, ziyarette bulunulan bölgenin kendine has niteliğine katkı sağlayan dikkat çekici unsurlarından biridir. (Güneş vd., 2008).

Yöresel yiyecek ve içecekler hangi yöreye aitse o yörenin tanıtılması için önemli bir araçtır (Zağralı ve Akbaba, 2015). Yöreye özgü yiyecek ve içecekler, o yöreye ait kültürün bir unsuru olarak potansiyel tanıtım aracı olmanın yanı sıra, aynı zamanda yerel ve ekonomik kalkınmanın parçası olma yönüyle o yörede güçlü bir etki yaratmaktadır (Šimić ve Pap, 2016: 10). Bir yemeğin hazırlanışında kullanılan malzemeler, coğrafya hakkında bilgi verirken, yemeğin lezzeti ve sunumu da ülkenin kültürü hakkında bilgi vermektedir. Bu bağlamda yöresel yemek kültürü toplumun izlerini taşımaktadır. (Yüncü, 2010). Aynı zamanda yöresel yiyecek ve içecekler, turizm ürünü olarak turistler için yeni bir pazar olması özelliği ile öne çıabilmektedir (Şengül ve Türkay, 2016: 90). Kişilerin yiyecek ve içecekleri yerinde tatma isteği, gastronomik açıdan zengin ve özgün niteliğe sahip destinasyonların tercih edilmesinde önemli rol oynamaktadır (Sünnetçioğlu vd., 2017). Bu bağlamda rakiplere göre üstünlük kazanmak isteyen destinasyonlar, rekabet avantajı sağlayacak özelliklerini öne çıarıp bunu pazarlama yoluna gitmelidir (Özdemir ve Karaca, 2009: 114). Destinasyonun dünya çapında bir marka değeri kazanabilmesi için sunduğu turistik ürünü oluşturan unsurların iyi analiz edilmesi ve bu analiz sonucunda belirlenen unsurların uluslararası turizm piyasasında ön plana çıkarılması gerekir (Avcıkurt, 2004: 1).

Somut olmayan kültürel miras değerlerinin turizm amaçlı kullanılması, insanların o bölgedeki yemek kültürüne tanıklık etmesi ve yörede yaşayanları anlaması yeni bir kültürü de tanımış olması anlamına gelmektedir. Mardin açısından düşünüldüğünde, yöresel yemeklerin Mardin destinasyon kimliğinin önemli bir unsuru olarak değerlendirilmesi gerektiği düşünülmektedir. Gastronomi turizmi açısından önemli çekiciliklere sahip olduğu düşünülen Mardin yemek kültürü detaylı olarak bir sonraki bölümde ele alınmıştır.

\section{Mardin Yemek Kültürü}

Genel anlamda yemek kültürü, yalnızca bir ülkenin mutfağına yönelik yeme ve içme faaliyetleri değil, aynı zamanda bu yeme ve içme faaliyetlerinin hazır hale gelmesi ve servis edilmesine 
yönelik yöntemler, kullanılan edevatlar, mutfağın genel yapısı, yemek sunumları ve diğer bazı benzer kavramları da içine almaktadır (Özdemir ve Kınay, 2004). Güneydoğu Anadolu Bölgesi bir bölge olarak 'Bereketli Hilal' diye nitelendirilmesi ve çeşitli medeniyetlere ev sahipliği yapması sebebiyle, Türkiye'nin mutfak Kültürü açısından çeşitlilik göstermesinde en büyük katkıyı sağlayan bölgelerden biridir (Aksoy ve Sezgi, 2015: 80). Yıllarca farklı kültürlere ev sahipliği yapmış olan Mardin ili bu sayede zengin bir yemek kültürüne sahip olmuştur. Kültürel anlamda seyahati tercih eden turistler bunun anlamlı bir parçası olan yemek kültürüne de bir o kadar önem vermektedirler. Mardin gastronomi turizmi kapsamında Türkiye' de ilk siralarda yer aldığı görülmektedir (Gürbüz vd., 2017: 126). Toprak (2018: 1100) Mardin'in yerel mutfağını oluşturan yemekleri, Acin, İncasiyye, Alo Mıhşı (Hindi Dolma), Kaburgaye, Yoğurt Çorbası, Şehriyeli Bulgur Pilavı, Etli Dolma, Alluciye, Irok, Şiişe Çorbası, Döbo, Kital İkbar/Kitel Raha, Merge, Lebeniye, Kınnebireli bulgur pilavı, Nane xweş, Sembusek, İhbeyz lahme, Nane Şikefti, ihbeyz ibcibne, Süryani Çöreği, Mevlit Çöreği, Helevitil cibne, Davk-1l May, Isfire, Zingil,Kibe, Merakıtılbayd, Selcemiye, Kariyye, Dahudiyet, Fırkıye, Kişkek, Döşirmeki, Pekmezli ve yağlı ekmek, Löziye, Kahiye, Imtabbaka, Pestil Helvası, Pekmez Şerbeti, Harire, Paskalya Çöreği, Badem Şekeri olarak sıralamaktadır. Bu yemeklerden otel işletmelerinin menülerinde yer alan yöresel yemeklerin ismi ve içerikleri çalışmanın bulgular bölümünde yer almaktadır.

Kültürel mirasın bir parçası olan yöresel yemekler (Serçeoğlu, 2014: 45) turizm faaliyetleri bağlamında Türkiye'de çok önemli bir alanı oluşturmakta ve Türkiye'de var olan sayısız destinasyon için olumlu imaj oluşturma sürecinde anahtar etkenlerden birisi durumundadır. Böyle zengin bir mutfağa sahip olan Mardin ilinde faaliyet gösteren konaklama tesislerinin, menülerinde yöresel yemekleri ne düzeyde tercih ettiklerinin belirlenmesi bu çalışmanın temel amacidır.

\section{Araştırmanın Amacı ve Önemi}

Türk mutfak kültürü ve yöresel mutfakla ilgili literatürde birçok çalışma bulunmaktadır. Bu çalışmalar yörede bulunan restoranların sundukları hizmetler üzerine odaklanmış, kırsal turizm kapsamında yöresel mutfakların rolüne vurgu yapmış, zengin mutfak kültürüne sahip olan farklı bölgelerde otel işletmelerinin sundukları yöresel yemekleri incelemiş ve/veya Mardin ilini ziyaret eden yerli yabancı turistlerin Mardin lezzetleri ile ilgili görüsslerini ele almıştır. Hatipoğlu vd., (2012) tarafından Gelveri'deki Rum evlerinden turizm işletmesi olarak faaliyet gösteren işletmelerin, menülerinde yöresel yemeklerin ne oranda kullanıldığı tespit etmişler ve aynı zamanda yemek üretim aşamasında yerel malzemelerin de kullanılması gerektiğini vurgulanmışlardır. Serçeoğlu (2014) yaptığı çalışmada Erzurum yöre halkının kendilerine ait mutfak kültürünü tanıyıp tanımadıklarını araştırmış, Erzurum halkının yöresel yemekleri unutmadıkları, evlerinde yaptıkları ve lezzetli buldukları sonucuna ulaşmıştır. Yarış (2014) tez çalışmasında Mardin ilinin gastronomisi hakkında yöreyi ziyaret eden 450 turistten görüş almış ve bölgede yöresel yemekler ile ilgili etkinliklerin yetersiz olduğuna, fiyatların yüksek olduğuna vurgu yapmış ve önerilerde bulunmuştur. Zağralı ve Akbaba (2015) İzmir yarımadasını ziyaret eden turistlerin bölgeyi ziyaretinde yöresel yemeklerin etkisini araştırmıştır. Araştırma sonucunda, yerel yemeklerin bölgenin tercih edilmesinde belirleyici bir rol oynamadığı tespit edilmiştir. Turistlerin bölgedeki konaklama süreci içinde yaşadıkları yemek deneyimlerinden genel olarak memnun olduğu, yerel yemekler noktasında tanıtım eksikliğinin söz konusu olduğu Zağralı ve Akbaba'nın (2015) araştırmada elde ettikleri diğer bulgulardır. Çokişler ve Türker (2015) çalışmalarında Ayder restoranlarının yöneticileri ile nitel bir görüşme yaparak, mutfak kültürünün turizm amaçlı kullanımını belirlemeye çalışmıştır. Ayder bölgesindeki restoran yöneticilerinin mutfak kültürünü turizm amaçlı kullanımı konusunda yeterince farkındalığa 
sahip olmadığı, turist sayısındaki artışa bağlı olarak yöresel mutfağın sunumunda yozlaşmalar yaşandığı tespit edilmiştir. Saatçi ve Demirbulat (2016) Travel Turkey 2014 İzmir fuar ve konferansına katılan destinasyonların tamamında yöresel yemekleri kullanma durumlarını incelemek için destinasyona katılanların tanıtım broşürleri incelemiş ve yöresel yemeklere yeteri kadar yer verilmediği sonucuna ulaşmıştır. Mil ve Denk (2015) Erzurum'un Palandöken ilçesinde yer alan turistik işletmelerin yöresel ürünleri menülerinde kullanma düzeyini araştırmış, bu işletmelerin menülerinde yöresel yemeklere yer vermekle birlikte, daha çok ulusal ve uluslararası ürünlere ağırlık verdikleri bulgusuna ulaşmıştır. Adana ve Mersin bölgesinde yapılan bir araştırmada ise 212 konaklama ve yiyecek içecek işletmesinden veri toplanmış, bu işletmelerden \%84,3'ünün yöresel yemeklere menülerinde yer verdiği belirlenmiştir (Yıldırım vd., 2018). İflazoğlu ve Yaman (2020) yaptıkları araştırmada doküman analizi yöntemi ile Mardin iline ait 34 yöresel yemek belirlemiş, Mardin'in önemli turist çekim merkezi olan 1.Cadde'deki yerel restoranların menülerinde 34 yemeğin $14^{\prime}$ üne hiç yer vermediğini tespit edilmiştir.

$\mathrm{Bu}$ araştırmada, bugüne kadar kültür turizmi ile ön plana çıkmış olan Mardin ilinde, yöresel yemeklerin konaklama işletmeleri tarafından ne kadar tanıtıldığı ve ziyaretçiler tarafından ne kadar talep edildiği, konaklama işletmeleri yöneticileri ile yüz yüze görüşülerek araştırılmıştır. Literatürde benzer şekilde yöresel yemeklerin turizm sektöründe kullanımına yönelik araştırmalar olmakla birlikte, otel işletmelerinin menülerinde yöresel yemeklerin kullanım düzeyi üzerine odaklanan araştırmalar oldukça sınırlıdır. Gastronomik anlamda oldukça zengin çekicilik unsurlarına sahip, kültür turizmi açısından önemli bir destinasyon olduğu düşünülen Mardin ili özelinde yöresel yemeklerin otel işletmeleri menülerinde kullanım düzeyini belirlemek, çalışmanın literatüre sağlayacağı önemli bir katkıdır.

\section{ARAŞTIRMA YÖNTEMI}

$\mathrm{Bu}$ araştırmada, nitel araştırma yöntemi kullanılmıştır. Araştırmanın içeriğini oluşturan veriler, nitel araştırma yöntemlerinde en sık kullanılan teknik olan, görüşme tekniği ile elde edilmiştir. Araştırmanın temel yaklaşımı nitel araştırma yönteminin tümevarım yaklaşımıdır. Tümevarım yaklaşımı, parçaların incelenmesini ve bu incelemelere dayanılarak bütünün tanımlanmasını amaçlayan bir yaklaşımdır (Hatipoğlu vd., 2012). Bu araştırmada nitel yönteminin kullanılmasının nedeni araştırma verilerinin, doğrudan, üst kademe yönetici görüşleri ile elde edilmek istenmesi ve bu kişilerin görüşlerinin nicel yöntemle elde edilmesinin zor olmasıdır.

Araştırmanın evrenini Mardin il merkezinde bulunan konaklama işletmeleri oluşturmaktadır. Bu araştırmada Mardin il merkezinin seçilme sebepleri ise; Türkiye'de dinler ve diller şehir olarak bilinen Mardin ilinin ülkemizde kültürel miras açısından büyük önem arz etmesi ve yörenin zengin mutfak kültürüne sahip olmasıdır. Araştırmaya dâhil edilen işletmelerle telefon ile yapılan görüşmeler sonucu randevu alınmış ve kabul edilen randevular sonucunda ulaşılabilen 3 , 4 ve 5 yıldızlı otellerin üst ve orta kademe yöneticileri çalışmaya katılımcı olarak dahil edilmiştir. Görüşme sırasında ses kayıt cihazı bulundurulmuş, katılımcıların izni dahilinde kayıt yapılmış ve önemli noktalar da ayrıca not alınmıştır. Görüşülen kişinin konu ile ilgili görüşlerini rahat bir şekilde ifade edebilmeleri için fiziki ve beşeri unsurların araştırmanın amacına uygunluğu sağlanmıştır. Bu bağlamda görüşmede kullanılan soru formunun oluşturulmasında, öncelikle yapılan literatür incelemesi dikkate alınmış ve sorular uzman kişiler tarafından incelendikten sonra araştırma yapılmıştır.

Bu bağlamda Mardin il merkezinde bulunun konaklama işletmelerinden 3, 4 ve 5 yıldızlı otellerin menülerinde kullanılan yöresel ürünleri belirlemek amacıyla bölgede bulunan altı adet otel işletmesinden faaliyet gösteren beş otel işletmesinin üst ve orta kademe yöneticileri ile "Yarı Yapılandırılmış Mülakat Tekniği" uygulanmıştır. Çalışmanın amacına yönelik olarak Mardin il 
merkezinde bulunan Ramada Hotel (Erdoba Elegance) (5 yıldız), Hotel Yay Grand (4 yıldız), Hilton Garden Inn (4 yıldız), Nuhoğlu Otel (3 yıldız) ve Büyük Mardin Oteli (3 yıldız) oterllerinin genel müdürleri ve aşçıbaşıları ile yüz yüze görüşmeler düzenlenerek, önceden hazırlanmış sorular yönlendirilmiş, alınan cevaplar kaydedilmiştir. Görüşme esnasında, konaklama işletmesiyle ilgili genel sorulardan, sunulan menüler ve menülerde kullanılan yöresel ürünlerin öğrenilmesi amacıyla geliştirilen daha özel sorulara doğru şekillenen bir format (ters huni tekniği) izlenmiştir. Elde edilen bilgilerin benzerlik ve farklılıklarını ortaya çıarmak amacıyla raporlanan görüşme notları çalışmanın bulgularında yorumlanmıştır.

\section{BULGULAR}

Araştırmaya katılan katılımcıların demografik özellikleri Tablo 1'de yer almaktadır. Bu bilgilere göre, katılımcıların tamamı erkek bireylerden oluşmaktadır. En genç katılımcı 26 yaşındayken katılımcıların yaş ortalamaları ise 35 yaşın üstündedir. Katılımcıların eğitim durumuna bakıldığında ilköğretim, orta öğretim ve ön lisans mezunu olduğu görülmektedir. Katılımcıların işletmedeki görevlerinin orta kademe ve üst kademe yönetici olmalarına rağmen eğitim durumlarının lisans ve lisansüstü olmaması en çok dikkat çeken unsur olmuştur. Katılımcıların yabancı dil bilgilerine bakıldığında ise 1 katılımcının İtalyanca bilmesi ve 3 katılımcının yabancı dilinin olmaması dikkat çeken bir diğer unsurdur. Çalışanların yabancı dil eğitiminin düşük olması, otel işletmelerindeki yönetici veya çalışanların işe alınırken yabancı dil bilgisinin önemli bir kıstas olmadığının göstergesi olarak yorumlanabilir. Ayrıca bölgeyi ziyaret eden ziyaretçilerin büyük çoğunluğunun yerli turist olmasından dolayı yöredeki otel işletmesi çalışanlarının Kürtçe ve Arapça dilleri dışında farklı dilleri bilmesinin önemli bir gereklilik olmadığı düşünülebilir. Ancak yöredeki yerel halkın ve otel işletmesi çalışanlarının yabancı dil bilgisinin yetersiz olması, yöreyi ziyaret eden yabancı turistlere karşı hizmet kalitesinin düşmesine sebep olabilmektedir. Bununla birlikte otel işletmelerindeki yöneticilerin ve çalışan personellerin yerli halktan oluşması da yöredeki istihdama katkı sağladığını göstermektedir.

Tablo 2'de araştırmaya dahil edilen otellerin isimleri yer almaktadır. Mardin ilinde bulunan bütün konaklama işletmelerindeki yöneticiler ile yüz yüze görüşmenin uzun zaman alması ve ulaşılabilme zorluğundan dolayı Mardin il merkezinde bulunan sadece yıldızlı otellerin yöneticilerinin örneklemi oluşturması araştırmanın sınırlılıklarını oluşturmaktadır. Ayrıca diğer konaklama işletmelerinin sadece oda veya oda kahvaltı konseptinde çalışması araştırma amacının dışında kalacağı düşünüldüğünden örnekleme dahil edilmemiştir.

Araştırmada katılımcılara yöneltilen sorular tema halinde aşağıda yorumlanmaktadır. Buna göre Menüde yöresel yemeklerin yer alma düzeyini belirlemeyi amaçlayan soruya verilen cevaplara bakıldığında katılımcıların tamamı menülerde yöresel yemeklerin yer aldığını belirtmiştir. İşletmelerin yöresel yemeklere genellikle ala'carte restorantlarında ve açık büfede yer verdikleri görülmektedir. Diğer katılımcılardan farklı olarak katılımcı 8 yöresel yemeklere hazırlık süresi uzun olduğu için sadece toplu yemeklerde yer verdiklerini belirtmiştir. Katılımcı 12 ise en çok talep edilen yöresel yemekleri menülerine dahil ettiklerini vurgulamıştır.

"Menüde hangi yöresel yemekler yer almaktadır" sorusu ile işletmelerin menülerinde yer alan yöresel yemeklerin neler olduğu belirlenmeye çalışılmıştır. "Kaburga Dolması, Höşo Mardin, Irok (içli köfte), İkbebet (haşlanmış içli köfte), Dobo (kuzu kol), İşkembe Dolması (mumbar dolması), Sembusek (kapalı pide), Alluciye (kuzu eti-erik), Tandır, Süryani Köftesi, Lebeni (Ayran/yoğurt çorbası)" menülerde yer alan yemekler arasındadır. Ayrıca, katılımcıların bir kısmı menüde yer almayan yemeklerin de var olduğunu ve bu yemekleri talebe göre sunduklarını belirtmiştir. Özellikle, yörenin mutfak kültürünü yakından tanıyan misafirler tarafından yöresel yemeklerin daha çok tercih edildiği katılımcıların aktardığı bir diğer ayrıntıdır. Bununla birlikte daha çok 
banket organizasyonu, dügün gibi toplu yemek organizasyonlarında otellerin tercih edildiği ve önceden hazırlık süreci olduğu için yöresel yemeklere otel işletmelerinin daha çok yer verilebildiği görülmektedir. Grup haricinde münferit misafirlerin ise genelde restoranları tercih ettikleri görülmektedir. Ayrıca, yaz aylarında etten oluşan yöresel yemeklerin çok tercih edilmediği belirtilmiştir. Bunun sebebi olarak yörenin çok sıcak olması ve bu yemeklerin ağır olması gösterilmiştir.

Tablo 1. Katılımcıların Demografik Özellikleri

\begin{tabular}{|c|c|c|c|c|c|c|}
\hline 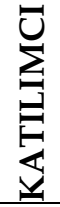 & 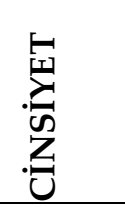 & $\sum_{\lambda}^{\infty}$ & 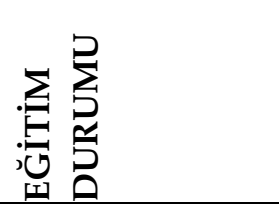 & 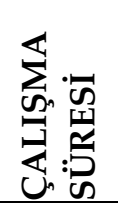 & 珗 & 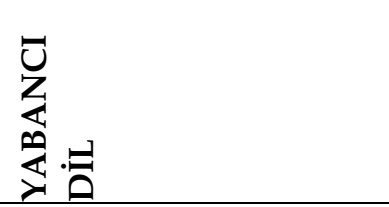 \\
\hline 1 & Erkek & 33 & Ön lisans & 4 & İşletme Müdürü & Arapça, Kürtçe \\
\hline 2 & Erkek & 52 & İlköğretim & 11 & Aşç1 & Yok \\
\hline 3 & Erkek & 35 & $\begin{array}{ll}\text { Lise } & \text { (orta } \\
\text { öğretim) } & \\
\end{array}$ & 13 & F\&B Müdürü & Yok \\
\hline 4 & Erkek & 37 & $\begin{array}{ll}\text { Lise } & \text { (orta } \\
\text { öğretim) } & \\
\end{array}$ & 6 & Kisım Şefi & Arapça \\
\hline 5 & Erkek & 26 & Ön lisans & 1 & Sicak Şefi & $\begin{array}{l}\text { İngilizce, İtalyanca, } \\
\text { Arapça }\end{array}$ \\
\hline 6 & Erkek & 38 & Ortaokul & 2 & Sicak Şefi & Yok \\
\hline 7 & Erkek & 33 & $\begin{array}{ll}\text { Lise } & \text { (orta } \\
\text { öğretim) } & \\
\end{array}$ & 3 & Ala'carte Şefi & İngilizce \\
\hline 8 & Erkek & 29 & Ön lisans & 9 & İşletme Müdürü & İngilizce, Arapça \\
\hline 9 & Erkek & 33 & $\begin{array}{ll}\text { Lise } & \text { (orta } \\
\text { öğretim) } & \\
\end{array}$ & 11 & İşletme Sahibi & Kürtçe \\
\hline 10 & Erkek & 36 & Ön lisans & 6 & İşletme Müdürü & İngilizce, Arapça \\
\hline 11 & Erkek & 47 & $\begin{array}{ll}\text { Lise } & \text { (orta } \\
\text { öğretim) } & \\
\end{array}$ & 10 & İşletme Müdürü & Arapça, Kürtçe \\
\hline 12 & Erkek & 28 & Ön lisans & 10 & İşletme Müdürü & İngilizce, Arapça \\
\hline
\end{tabular}

Tablo 2. Araştırmaya Dahil Edilen Oteller

\begin{tabular}{|l|c|}
\hline Otelin Adı & Yıldız \\
\hline Ramada Plaza by Wyndham Mardin & $5^{*}$ \\
\hline Yay Grand Otel & $4^{*}$ \\
\hline Hilton Garden Inn & $4^{*}$ \\
\hline Büyük Mardin Otel & $3^{*}$ \\
\hline Nuhoğlu Otel & $3^{*}$ \\
\hline
\end{tabular}

Otel işletmeleri menülerinde yer alan bütün yiyeceklerin satışının içerisinde yöresel yemeklerin oranını belirlemeye yönelik soruda katılımcıların çoğu (n: 9) yöresel yemekleri menülerinde bulundurduğunu ifade etmişlerdir. Menülerinde yöresel yemeklerin ortalama \%70-75 oranında yer verildiğini belirtmişlerdir. Ancak katılımcı 3 otel işletmesinin sadece oda satışı yaptıkları için 
menülerinde yöresel yemek bulundurmadıklarını ve sadece talep olması durumunda sunduklarını belirtmiştir. Buna benzer olarak katılımcı 5 de sadece banket organizasyonlarında yöresel yemeklere yer verdiklerini söylemiştir. Katılımcı 12 ise sadece grup rezervasyonlarında talebe göre yöresel yiyecekleri arz ettiklerini belirtmiştir. Ayrıca yabancı turistlerin yöresel yemeklerin genellikle küçükbaş hayvanlardan yapılması ve kokusunun ağır olmasından dolayı tercih etmediklerine vurgu yapmıştır.

Yöresel yemekler arasında en çok tercih edilen yemeğin belirlenmesine yönelik soruya katılımcıların çoğunluğu müşteriler tarafından en fazla kaburga dolmasının tercih edildiği cevabını vermiştir. Ancak kaburga dolmasının hazırlanışının uzun sürmesi ve sunumunun özel olması sebebiyle bu yemeği daha önceden sipariş alarak sunabildiklerini ifade etmişlerdir. Daha sonra Irog yemeğinin de çok tercih edildiğini belirten katılımcılar sıcak ve soğuk yöresel yiyecekleri bir arada bulunduran "Mardin Tabă̆ı" nın da çok tercih edildiğini belirtmişlerdir.

Yöresel yemekler ile diğer yemekler arasında fiyat farkının olup olmadığına ilişkin soruda katılımcıların çoğunluğu (n:10) fiyat farkının olduğunu ve bunun yemeklerin birçoğunun hammaddesinin et olması ve et maliyetlerinin yüksek olması ile ilişkili olduğunu ifade etmiştir. Ayrıca, Mardin'e özel yemeklerin başka yörede sunulmaması fiyat faktörü üzerinde etki yaratmaktadır.

Yöresel yemeklerin sunumunda (dekor-tabak düzeni) farklılık olup olmadığına ilişkin soruda bütün katılımcılar tabakların dekorlarında farklılıkların olduğu ancak her işletmenin farklı dekorlar ile sunum yapabildiğini belirtmiştir. Yemeklerden sadece kaburga dolmasının sunumunda yöre kültürüne özgü yöresel sinilerde sunum yapıldığına vurgu yapmışlardır.

İşletmelerin yöresel yemeklerin tanıtımına ne derecede katkıda bulunulduğuna ilişkin soruda katılımcıların tümü yörenin yemek tanıtımına katkıda bulunduklarını belirtmişlerdir. Otel işletmesinin web sayfasında Mardin mutfağına vurgu yaptıklarını ve gelen misafirlere yöresel yemekleri mutlaka önerdiklerini ve içeriklerinden bahsettiklerini ifade etmişlerdir. Ayrıca menülerinde yöresel yemeklere yer vererek, bu yemeklerin tanıtımına katkı sağladıklarını düşünmektedirler.

Kültürlerarası yöresel yemeklerin tercihlerinde anlamlı bir ilişkinin olup olmadığına ilişkin soruda katılımcıların tümü kültürlerarası farkın olduğunu belirtmiştir. Yöre halkının kahvaltıda özellikle kavurma yemek isterken, yöre dışından gelen turistlerin bu tür isteklerinin olmamasını bu durumun bir örneği olarak göstermişlerdir. Yabancı turistlerden ise genellikle Arap turistlerin yemek kültürüne sıcak baktığını diğer ırkların çok sıcak bakmadığını ifade etmişlerdir.

Menüde bulunan yöresel yemek üretiminde yöreye ait hammadde kullanımına ilişkin soruda genellikle salça, hayvansal iç yağ ve baharatların (pul biber, yeni bahar, isot, kişniş) çok kullanıldığını, bu ürünlerinde yöreyi temsil ettiği ve yöresel yemek tatlarının hammadde ile belirlendiği ifade edilmiştir.

\section{SONUÇ ve ÖNERILER}

Mardin ilinde faaliyet gösteren otel işletmeleri üzerinde gerçekleştirilen araştırma kapsamında 5 adet otel işletmesinden 12 orta kademe ve üst kademe yöneticiden mülakat yöntemiyle veri toplanmıştır. Yerel mutfak kültürüne otel işletmelerinde ne kadar önem verildiğini belirlemek amacıyla katılımcılara ilk olarak menülerinde yöresel yemeklere yer verip vermedikleri sorulmuştur. Katılımcıların tamamı menülerinde yöresel yemeklere yer verdiklerini belirtmiştir. Bu sonuç Yıldırım vd., (2018) tarafından Adana ve Mersin bölgesinde yapılan araştırma sonuçlarıyla paralellik göstermektedir. İflazoğlu ve Yaman'ın (2020) yerel restoranların menülerinde 34 yemeğin 14'üne hiç yer vermediği tespiti ise araştırmanın bulgularıyla farklılık 
göstermektedir. Ziyaretçiler içinde yörede yaşayan insanların oranının yüksek olması, yöresel yemeklerin menüde yer almasını bir gereklilik haline getirmektedir. Yöresel yemeklere, hem gastro turist olarak nitelendirebileceğimiz turist kitlesinin, hem de yiyecek içecek alışkanlığ1 olarak yöresel yemekleri tüketmeyi alışkanlık haline getirmiş yerel halkın talebinden söz etmek mümkündür. Özellikle yörenin mutfak kültürünü yakından tanıyan misafirlerin yöresel yemekleri daha çok tercih ettiği katılımcılar tarafından vurgulanmıştır.

Menülerde yer alan yöresel yemeklerin isimlerini belirlemeyi amaçlayan soruya verilen cevaplar yörede birçok özgün yemeğin var olduğunu göstermektedir. Ayrıca, menülerde genellikle en çok bilenen ve talep edilen yöresel yemeklere yer verildiği, bu yöresel yemeklerin dışında da talebe göre farklı yöresel yemekleri müşterilere servis edebildiklerini birçok katılımcı dile getirmiştir.

Yöresel yemeklerin otel işletmelerinin menülerinde yer alan bütün yiyeceklerin satışı içerisinde yaklaşık \% 70 gibi bir pay aldığı katılımcıların geneli tarafından ifade edilmiştir. Bu oranın oldukça yüksek bir oran olduğu söylenebilir. Bu veri yöresel yemeklerin menülerde yer almasının talep olarak karşılık bulduğunu göstermektedir. Bununla birlikte katılımcılardan bazıları özel etkinliklerde ve banket organizasyonlarında yöresel yemeklere daha çok yer verildiğini ifade etmiştir. Yöresel yemeklerin hazırlanma süresinin diğerlerine göre daha uzun olması sebebiyle, bu yemekler ön hazırlık süresi daha uzun organizasyonlarda daha çok tercih edilmektedir. Yöresel yemekler arasında en çok kaburga dolması, Irog ve Mardin tabağ tercih edilmektedir. Kaburga dolması hazırlanma süresi uzun olduğu için özellikle banket organizasyonlarında yoğunlukla tercih edilmektedir.

Katılımclardan elde edilen verilere göre yöresel yemeklerin fiyat farkının olduğu anlaşılmaktadır. Bu fiyat farkının temel sebebi olarak birçok yemeğin hammaddesinin et olması ve et maliyetlerinin yüksek olması gösterilmiştir. Yöreye özgü olan yöresel yemeklerin fiyatlarının belirli bir düzeyde yüksek olması, başka bir yerde deneyimlenme şansı olmaması ve özel olması sebebiyle misafirler tarafından kabul edilebilir bir durumdur. Yöresel yemeklerin sunumunda işletmelere göre farklılıklar olduğu görülmektedir. Özellikle kaburga dolması yöresel sinilerde servis edilmesinden dolayı sunumda daha otantik bir özellik taşımaktadır.

Katılımcların tümü yörenin yemek tanıtımına katkıda bulunduklarını belirtmişlerdir. Katılımclardan bir kısmı otel işletmelerinin web sayfasında Mardin mutfağına vurgu yaptıklarını ve gelen misafirlere yöresel yemekleri mutlaka önerdiklerini ve içeriklerinden bahsettiklerini ifade etmiştir. Ancak, araştırmak kapsamındaki otellerin web siteleri incelendiğinde görseller dişında çok fazla yöresel yemeklerle ilgili bilgiye yer verilmediği görülmüştür. Yöresel yemeklerin tercih edilmesinde misafirlerin kültürüne göre farklılık olup olmadığı sorulduğunda katılımclar böyle bir farklılığın var olduğunu özellikle Arap turistlerin yöresel yemekleri tercih etme eğiliminin daha yüksek olduğunu belirtmiştir. Menüde bulunan yöresel yemek üretiminde yöreye ait hammaddelerin kullanılıp kullanılmadığı sorulduğunda, genellikle salça, hayvansal iç yağ ve baharatların (pul biber, yeni bahar, isot, kişniş) çok kullanıldığı ifade edilmiştir.

Yöresel yemek kültürü somut olmayan kültürel mirasın önemli bir parçasıdır ve ziyaretçilerin yöresel yemek kültürünü deneyimleyerek otantik bir deneyim yaşamasını sağlamaktadır (Okumuş vd., 2007). Araştırma katılımcılarından elde edilen bulgulara bakıldığında genel olarak işletmelerin menülerinde yöresel yemeklere yer verilmekle birlikte, bu yemeklerin yöre kültürüne yakın kişilerin tüketim alışkanlıklarına hitap etmesi amacıyla sunulduğu söylenebilir. $\mathrm{Bu}$ durumun Mardin yöresel yemeklerinin yeterince markalaşmış olmamasından kaynaklandığ 1 söylenebilir. Yöresel yemeklerle ilgili gelecekte bir marka değerinin yaratılması sadece bu yemekleri deneyimlemek için gastro turist olarak nitelendirilen kitlenin Mardin'e çekilmesine katkı sağlayacaktır. Ayrıca, destinasyonlarda yöresel yemek kültürünün destekleyici bir ürün 
olarak kullanılması ziyaretçilerin memnuniyet sağlayarak bölgeyi tekrar ziyaret etmeleri ya da otel işletmelerinde kalış sürelerini uzatabilmelerini sağlamaktadır (Şengül ve Türkay, 2016). Bu nedenlerle, yöresel yemeklerin tanıtımı ile ilgili çalışmalara önem verilmesi Mardin'in marka değerini arttırmak açısından son derece faydalı olacaktır. Bu amaca yönelik olarak, geleneksel medyada ve sosyal medyada Mardin'e has yiyecek içecekler ile ilgili tanıtım içerikleri oluşturmak faydalı olacaktır. Özellikle sosyal medyanın sağlayağı etkileşimin katkısı Mardin yemek kültürünün ön plana çıkarılmasında kullanılabilir. Ayrıca, otel işletmelerinde sunulabilecek yöresel yemeklerle ilgili çalışmaların yapılması ve bu çalışmaların çeşitli organizasyonlarla meslek üyeleri ile paylaşılması, menülerde daha zengin içeriklerin sunulmasını sağlayacaktır. Bu noktada Mardin' de yer alan turizmle ilgili meslek örgütlerine önemli roller düşmektedir.

Araştırma bulguları genel olarak Mardin'de faaliyet gösteren otel işletmelerinin menülerinde yöresel yemeklere yer verildiğini, fakat bu yemeklerin daha çok yöre kültürüne yakın yerli turistler tarafından tercih edildiğini göstermektedir. Bu durum bölgeye çok fazla gastronomi turizmi amaçlı olarak yabancı ziyaretçinin gelmediğini düşündürmektedir. Bu noktada gastronomi anlamındaki çekiciliklerin yabancı ziyaretçiler açısından ne derece önemli olduğunu belirlemek, gelecekte yapılacak araştırmalar için konu oluşturabilir. TÜRSAB yayınladığı gastronomi turizmi raporunda (www.tursab.org.tr), gastronomi turizminde başarının sağlanabilmesi için çeşitli etkinliklerin geliştirilmesi gerektiğine vurgu yapmıştır. Bu etkinlikler içerisinde, aşçılık work-shop'ları, yemek etkinlikleri, gıda fuarları, pazar ve üretici gezileri ve yemek turları sıralanmıştır. Mardin'deki otel işletmeleri bu etkinliklerden bir kısmını düzenleyerek, hem iş hacimlerini arttırma fırsatı yakalayabilecek, hem de Mardin'de gastronomi turizminin gelişmesine önemli katkılar sağlayabilecektir.

\section{KAYNAKÇA}

Aksoy, M. ve Sezgi, G (2015). Gastronomi Turizmi ve Güneydoğu Anadolu Bölgesi Gastronomik Unsurlar1. Journal of Tourism and Gastronomy Studies, 3 (3), 79-89.

Akgöl, Y. (2012). Gastronomi Turizmi Ve Türkiye'yi Ziyaret Eden Yabancı Turistlerin Gastronomi Deneyimlerinin Değerlendirilmesi, Yayımlanmamış Yüksek Lisans Tezi, Mersin Üniversitesi Sosyal Bilimler Enstitüsü, Mersin.

Avcıkurt, C. (2004). Ülke İmajı ve Turizm İlişkisi-Türkiye Örneği. Haftasonu Turizm Konferansı IXTuristik Yerlerin (Destinasyonların) Pazarlanması, 17-19 Ekim. Nevşehir: Erciyes Üniversitesi Nevşehir Turizm işletmecilik ve Otelcilik Yüksekokulu.

Bilgili, B., Yağmur. Ö., ve Yazarkan, H. (2012). Turistik Ürün Olarak Festivallerin Etkinlik ve Verimliliği Üzerine Bir Araştırma (Erzurum-Oltu Kırdağ Festivali Örneği), Uluslararası Sosyal ve Ekonomik Bilimler Dergisi, 2(2), 117-124.

Bucak, T. ve Aracı, Ü. E. (2013). Türkiye'de Gastronomi Turizmi Üzerine Genel Bir Değerlendirme, Balıkesir Üniversitesi Sosyal Bilimler Enstitüsü Dergisi, 16 (30), 203-216.

Bucak, T. ve Ateş, U. (2014). Gastronomi turizminin il turizmine etkisi: Çanakkale örneği, International Journal of Social Science, 28 (2) 315-328.

Büyükşalvarcı, A., Şapçılar, M. C. ve Yılmaz, G. (2016). Yöresel Yemeklerin Turizm İşletmelerinde Kullanılma Durumu. Journal of Tourism and Gastronomy Studies, 4 (4), 165-181.

Çokişler, N. ve Türker, A. (2015). Mutfak Kültürünün Turizm Ürünü Olarak Kullanım Etkinliğinin İncelenmesi: Ayder Turizm Merkezi Örneği. Gümüşhane Üniversitesi Sosyal Bilimler Elektronik Dergisi, 6 (14), 122-136. 
De Silva, G. G. (2003). International Dictionary of Gastronomy, New York: Hippocrene Books, Inc.

Güler, O., Benli, S., Akdağ, G. ve Çakıcı, A. C. (2016). What Is Your Favorite Local Food Menu: Application of Conjoint Analysis on the Eastern Mediterranean Cuisine of Turkey. Journal of Tourism and Gastronomy Studies, 4 (3), 38-52.

Güneş, G., Ülker, H. İ. ve Karakoç, G. (2008). Sürdürülebilir Turizmde Yöresel Yemek Kültürünün Önemi. II. Ulusal Gastronomi Sempozyumu ve Sanatsal Etkinlikler. 10-11 Nisan. Antalya: Akdeniz Üniversitesi Alanya İşletme Fakültesi.

Gürbüz, S., Serçek, G. Ö. ve Toprak, L. (2017). Mardin'in UNESCO Yaratıcı Şehirler Ağında "Gastronomi Kenti" Olabilirliğine İlişkin Paydaş Görüşleri, Journal of Tourism and Gastronomy Studies, 5 (1), 124-136.

Hatipoğlu, A. (2010). İnançların Gastronomi Üzerine Etkileri: Bodrumdaki Beş Yıldızlı Otellerin Mutfak Yöneticilerinin Görüşlerinin Belirlenmesine Yönelik Bir Araştırma, Yayımlanmamış Yüksek lisans Tezi, Sakarya Üniversitesi Sosyal Bilimler Enstitüsü, Sakarya.

Hatipoğlu, A., Zengin, B., Batman, O. ve Şengül, S. (2012). Yöresel Yemeklerin, Kırsal Turizm İşletmeleri Mö nülerinde Kullanım Düzeyleri: Gelveri Örneği, Uluslararası Sosyal ve Ekonomik Bilimler Dergisi, 3(1), 6-11.

Hjalager, A.M. and Richards, G. (2004). Tourism and Gastronomy. London: Routledge.

https://www.tursab.org.tr/e-dergi?pdf=apps/OldFiles//dosya/12302/tursab-gastronomi-turizmiraporu_12302_3531549.pdf (Erişim Tarihi: 21.12.2020).

İflazoğlu, N. ve Yaman, M. (2020). Yöresel Mutfakların Gastronomi Turizminde Yer Alma Durumu: Mardin Yerel Restoran Menülerinin İncelenmesi, Journal of Tourism And Gastronomy Studies, 8 (3), 1943-1957.

Johns, N. and Clarke, V. (2001). Mythology Analysis of Boating Tourism. Annals of Tourism Research, 28 (2), 334-359.

Johns, N. and Kivela, J. (2001). Perceptions of The First Time Restaurant Customer. Food Service Technology, 1(1), 5- 11.

Kan, M. H. ve Kaynakçı, E. C. (2009). Antik Çağdan Bugüne Anadolu Yemekleri, II. Geleneksel Gidalar Sempozyumu, 27-29 Mayıs, Van.

Kızılırmak, İ., Albayrak, A. ve Küçükali, S. (2014). Yöresel Mutfağın Kırsal Turizm İşletmelerinde Uygulaması: Uzungöl Örneği. Uluslararası Sosyal ve Ekonomik Bilimler Dergisi, 4 (1), 75-83.

Köten, M., Ünsal, A. S., ve Atlı, A. (2010). İkliçe. 1. Uluslar arası “Adriyatik'ten Kafkaslar'a Geleneksel Gıdalar" Sempozyumu, 15-17 Nisan, Tekirdağ.

Lordkipanidze, M., Brezet, H. and Backman, M. (2005). The Entrepreneurship Factor in Sustainable Tourism Development. Journal Cleaner Production, 23 (3), 787-798.

Mil, B. ve Denk, E. (2015). Erzurum Mutfağı Yöresel Ürünlerin Otel Restoran Menülerinde Kullanım Düzeyi: Palandöken Örneği, International Journal of Social and Economic Sciences, 5 (2), 01-07.

Okumuş, B., Okumuş, F., and McKercher, B. (2007). Incorporating Local and International Cuisines in the Marketing of Tourism Destinations: The Cases of Hong Kong and Turkey. Tourism Management, 28 (1), 253-261. 
Özdemir, B. ve Kınay, F. (2004). Yabancı Ziyaretçilerin Türk Mutfağına İlişkin Görüşleri: Antalya'yı Ziyaret Eden Alman ve Rus Turistler Üzerine Bir Araştırma. Gazi Üniversitesi Ticaret ve Turizm Eğitim Fakültesi Dergisi, 2,5-28.

Özdemir, Ş. ve Karaca, Y. (2009). Kent Markası ve Marka İmajının Ölçümü: Afyonkarahisar Kenti İmajı Üzerine Bir Araştırma. Afyon Kocatepe Üniversitesi İ.̇.B.F. Dergisi, 11 (2) 113-134.

Saatçi, G. ve Demirbulat, Ö. (2016). Yöresel Yemeklerin Broşürlerde Tanıtım Unsuru Olarak Kullanılmasının Analizine Yönelik Bir Araştırma. Uluslararası Sosyal Araştırmalar Dergisi, 42: 1999-2006.

Semerci, H. (2018). Bodrum "a Gelen Uluslararası Ziyaretçilerin Yerel Yemek Tüketimindeki Motivasyon Faktörlerinin Değerlendirilmesi, Yüksek Lisans Tezi, İzmir Katip Çelebi Üniversitesi Sosyal Bilimler Enstitüsü, İzmir.

Serçeoğlu, N. (2014). Yöre Halkının Mutfak Kültürünü Tanıma Durumunun Tespit Edilmesi: Erzurum İli Örneği. Journal of Tourism and Gastronomy Studies, 2 (4), 36-46.

Šimić, M. L. and Pap, A. (2016). Can Food Be A Competitive Advantage of Croatian Tourism? Ekonomski Vjesnik/Econviwes, (1), 9-20.

Sünnetçioğlu, A., Yalçınkaya, P., Olcay, M. ve Okan, Ş. (2017). Turizm Alanında Yazılmış olan Gastronomiye İlişkin Tezlerin Bibliyometrik Profili. Journal of Tourism and Gastronomy Studies, 5 (2), 345-354.

Şengül, S. ve Türkay, O. (2016). Akdeniz Mutfak Kültürünün Gastronomi Turizmi Bağlamında Değerlendirilmesi. Journal of Tourism and Gastronomy Studies, 4 (1), 86-99.

Toprak, L., Güngör, A.Ç ve Gürbüz, S. (2018). Mardin Geleneksel Yemekleri ve Bu Yemeklerde Kullanılan Gıda Maddeleri. Zeugma I. Uluslararası Multidisipliner Çalışmalar Kongresi. 13-16 Eylül, Gaziantep.

Üner, E. H. (2014). Her Şey Dahil Sistemde Türkiye Gastronomi Turizmi Potansiyelinin Değerlendirilmesi. Yayımlanmamış yüksek lisans tezi, Atılım Üniversitesi Sosyal Bilimler Enstitüsü, Ankara.

Yarış, A. (2014). Mardin'de Gastronomi Turizmi: Turist Görüşlerine Illişkin Bir Uygulama, Yayımlanmamış Yüksek Lisans Tezi, Mardin Artuklu Üniversitesi Sosyal Bilimler Enstitüsü Turizm İşletmeciliği ve Otelcilik Anabilim Dalı Gastronomi Turizmi Bilim Dalı, Mardin.

Yergaliyeva, A. (2011). Destinasyon Markalaşma Sürecinde Yerel Mutfağın Yeri (Uralsk Bölgesi'ndeki Restoranlar Üzerine Bir Araştırma). Yayınlanmamış Yüksek Lisans Tezi, Balıkesir Üniversitesi Sosyal Bilimler Enstitüsü, Balıkesir.

Yıldırım, O., Karaca, O. B. ve Çakıcı, A.C. (2018). Yöresel Yemeklere Konaklama ve Yiyecek İçecek İşletmelerinin Menülerinde Yer Verilme Durumu: Adana ve Mersin Bölgesinde Bir Araştırma, Journal of Tourism and Gastronomy Studies, 6 (4), 376-398.

Yüncü, H. R. (2010). Sürdürülebilir Turizm Açısından Gastronomi Turizmi Ve Perşembe Yaylası, 10. Aybastı-Kabataş Kurultayı Aybastı-Kabataş Kurultayı Yayınları, Ankara: Detay Yayıncılık

Zağralı, A. ve Akbaba, A. (2015). Turistlerin Destinasyon Seçiminde Yöresel Yemeklerin) Rolü: İzmir Yarımadası'nı Ziyaret Eden Turistlerin Görüşleri Üzerine Bir Araştırma. Journal of Yaşar University, 10 (40), 6633-6644. 